\title{
A MAJOR MisundERSTANDING OF MINORS' CONTRACTS? ENFORCEMENT AND RESTITUTION UNDER THE MINORS' CONTRACTS ACT 1969
}

\author{
James Gilbert*
}

The Minors Contracts Act 1969 divides minors' contracts into two categories - those which are presumptively enforceable against the minor in the absence of unconscionability or oppression, and those which are presumptively unenforceable with an allowance for the exercise of judicial discretion to order remedies of enforcement, compensation or restitution depending on the fairness and reasonableness of the contract. This article focuses on judicial interpretation and application of the law with respect to the latter category, particularly in the case of Wine Country Credit Union v Rayner. It argues that the decision in Rayner to deny the possibility of a restitutionary or compensatory order in favour of the plaintiff lender was incorrect and contrary to parliamentary intention, and that reform of the law relating to minors' contracts is necessary to avoid a repeat of those errors.

\section{INTRODUCTION}

The Minors' Contracts Act 1969 (the Act) was the first of several contract statutes that replaced common law with a mixture of statutory rules and judicial discretions. The Act was and remains unique among common law jurisdictions in its approach to the law of minors' contracts.

The difficulty with minors' contracts law has always been determining how best to provide protection for young people without unduly obstructing the dealings of honest traders. ${ }^{1}$ The task has not been made easier by the changing social and economic conditions. Much of the common law position that preceded the Act was developed in Victorian times, when the offspring of wealthy English landowners often came into vast amounts of wealth at a young age, and became targets of

* Submitted as part of the LLB(Hons) programme at Victoria University of Wellington. Many thanks to Professor David McLauchlan.

1 Morrow \& Benjamin Ltd v Whittington [1989] 3 NZLR 122 (HC) at 124 per Thorp J. 
unscrupulous traders looking to take advantage of their inexperience. ${ }^{2}$ Such conditions did not prevail in New Zealand, and in the mid-1960s the New Zealand Government began the search for an alternative that would better suit the young population, which was far from affluent but nevertheless was disadvantaged from time to time by the inability to enter into binding contracts. The search culminated in the enactment of the Minors' Contracts Act 1969.

The Act allowed minors to enter into binding contracts in a handful of limited areas, and aimed to protect minors in other areas by creating a presumption of unenforceability which could only be surmounted through judicial discretion. The discretion could only be exercised where the Court was satisfied that the contract was fair and reasonable. Where it was not, other discretionary powers remained to ensure that the Court was able to reach a just resolution.

In the 40 year life of the Act the presumption of unenforceability has been tested in the High Court in only two reported cases, Morrow \& Benjamin Ltd v Whittington in 1989 and Wine Country Credit Union v Rayner in 2008. In both cases the Court declined the applications for enforcement by the plaintiff companies, who had advanced credit to minors which had not been repaid, on the basis that the contracts were not fair and reasonable. The dearth of case law on the subject has led both judges and academics to herald the Act as a success. ${ }^{3}$

This article aims to challenge that conclusion, in particular with respect to the presumption of unenforceability, and compensation and restitution orders. It will be argued that rather than creating a system whereby minors are adequately protected with minimal obstruction to commerce, the Act has created a system that is too uncertain to allow traders and lenders to even contemplate dealing with minors, and potentially denies recovery to adult parties even where doing so would produce the most just result. Exacerbating the problem is a misunderstanding by the High Court in Wine Country Credit Union $v$ Rayner of the relationship between the inquiry into fairness and reasonableness and the jurisdiction to exercise the discretionary powers to make compensatory and restitutionary orders for which the Act provides, and a failure to exercise these in a manner consistent with the objectives of the legislation.

This article first outlines the legal position prior to the Act and the associated difficulties with enforcement and recovery under that system. Second, it examines the key provisions in the Act relating to enforcement contained in ss 5, 6 and 7. Third, it outlines the application of those provisions in the cases of Morrow \& Benjamin Ltd $v$ Whittington and Wine Country Credit Union $v$ Rayner, the two cases where the High Court has been asked to determine enforceability of minors'

2 United Kingdom Law Commission Law of Contract: Minors' Contracts (Working Paper No 81, London, 1982) at 26.

3 Morrow \& Benjamin, above n 1; Wine Country Credit Union v Rayner [2008] 1 NZLR 698 (HC); Law Commission Contract Statutes Review (NZLC R25, 1993) at 238; Burrows, Finn and Todd Law of Contract in New Zealand (2nd ed, LexisNexis, Wellington, 2002) at 479. 
contracts under s 6 . This is followed by an analysis of the approach in Rayner, with the emphasis on three crucial errors in the High Court's reasoning, which indicate that the case may have been wrongly decided. Fifth, options for reform of the law are considered.

\section{ENFORCEABILITY PRIOR TO THE ACT A "Necessaries"}

One of the aims of the Minors' Contracts Act 1969 was to remedy a number of defects in the existing common law and statutory rules that had become apparent in first half of the 20th Century. At common law a person was an "infant", lacking capacity to contract, until they reached the age of $21 .{ }^{4}$ However, some provision was made for enforceability against an infant in very limited circumstances, on the basis that an absolute inability to contract could cause significant hardship for an infant.

A contract could be enforced against an infant where the contract was for the infant's benefit. ${ }^{5}$ Included among the contracts made binding by this rule were contracts for apprenticeships, education and employment, the reasoning being that it is beneficial both to the infant and to society that the infant should be able to contract for instruction in a trade. ${ }^{6}$

More controversially, the common law provided that infants' contracts for "necessaries" - goods or services necessary to the lifestyle of the infant - were also binding. The concern was that infants who, for whatever reason, could not resort to an adult for the provision of such goods or services could be subjected to significant hardship if the law precluded them from obtaining those things for themselves through contract. The concept of "necessaries" was therefore devised to enable infants to enter contracts for the things they really needed, whilst remaining protected from juvenile impulses to imprudently indulge in luxuries.

The concept was controversial because its definition varied depending on the infant's social status. The definition of "necessaries" covered not only necessities for life such as food, accommodation, clothing, and medicine, but also any "articles fit to maintain the particular person in the state, station and degree of life in which he is". ${ }^{7}$ The consequence of this was that what could be considered "necessaries" was different in every case. Determination of the point was often left to juries, whose application of the definition appears to have depended very much on a moral judgment of whether the minor defendant ought to be held to his or her promise. In the 1868 case of Ryder $v$

4 The age of capacity is said to derive from medieval times. 21 years was considered the age at which a knight's son was capable of bearing a suit of armour and lifting a sword. See Lord Elwyn-Jones (2 December 1986) 482 GBPD HL 711.

$5 \quad$ Roberts $v$ Gray [1913] $1 \mathrm{~KB} 520$.

$6 \quad$ Walter $v$ Everard [1891] 2 QB 369 at 175 per Fry LJ.

$7 \quad$ Peters $v$ Fleming (1840) $6 \mathrm{M} \& \mathrm{~W} 42$ (Ex) at 46 per Parke B. 
Wombwell, for example, a jury found an antique goblet and bejewelled cufflinks (purchased on credit as a present for the Marquis of Hastings), to be necessary for the maintenance of the infant defendant, the son of a deceased baronet in receipt of an annual allowance of $£ 500$ (around $£ 40,000$ by today's reckoning). ${ }^{8}$

The infant's supply of the goods in question at the time of entry into the contract also had to be considered. This meant that recovery was not assured even where a plaintiff could show that the goods in question prima facie satisfied the common law definition. If the infant defendant was already adequately supplied with such goods at the time of purchase, the purchased goods did not qualify as necessaries. ${ }^{9}$

Because of the uncertainty relating to the definition of "necessaries" it became easier for traders to avoid the difficulty of determining the issue by either requiring an adult indemnifier for infants' contracts or simply declining to deal with infants altogether. By the 1960s it was apparent to the United Kingdom Committee on the Age of Majority (Latey Committee) ${ }^{10}$ that the concept had ceased to have its desired effect. In its 1967 report the Committee acknowledged that the doctrine of "necessaries" was obsolete - there was no evidence that the liability of infants for "necessaries" caused any greater predisposition among traders to allow minors to deal on credit. ${ }^{11}$

This disinclination to deal with infants meant that those infants who were rash and careless with money, or who were commercially inexperienced and vulnerable to high pressure selling techniques, were well protected. But the inability to contract caused problems for scrupulous and commercially savvy infants who wished to utilise their talents in business. Any infant wishing to engage in commercial activities such as purchasing real estate, entering a business partnership or obtaining goods on credit was required either to seek the assistance of an adult indemnifier or convince the potential contracting party that the required goods or services were necessaries. Both options were decidedly cumbersome for an infant who wished to conduct such business on a regular basis or with a variety of different parties.

\section{B Alternative Causes of Action}

Under common law an unscrupulous infant had very little to fear as a consequence of inducing an adult party into a contract through fraudulent misrepresentation.

$8 \quad$ See Ryder $v$ Wombwell (1868) LR 4 Ex 32. The trial judgment was subsequently overturned on the basis that there was no evidence to indicate the question of necessaries should properly have been left to the jury.

$9 \quad$ Nash v Inman [1908] 2 KB 1 (CA).

10 Named for its chairman, Justice John Latey.

11 Report of the Committee on the Age of Majority (Cmnd 3342, 1967) at 84. 


\section{Tort}

While an infant was no less liable at common law for his or her tortious actions than an adult, the courts typically held that an infant who induced an adult party to contract with him or her through misrepresentation could not be liable in deceit because liability in such a situation would frustrate the common law's ability to protect the infant from making improvident bargains. In $R$ Leslie Ltd $v$ Sheill the infant took advantage of this principle to induce a moneylender to lend him $£ 400$, which he then spent and refused to repay. ${ }^{12}$ Lord Sumner, while recognising that the law needed to protect the infants from those wicked enough to contract with him, ${ }^{13}$ expressed regret that "no exception was made where, as here, the infant's wickedness was at least equal to that of the person who contracted with him". ${ }^{14}$

\section{Equity}

The ability to recover in equity was similarly limited. Where an infant continued to retain the benefits of a contract unenforceable due to infancy, equity made some provision for the adult party to recover benefits conferred, but only where the infant had procured the contract through fraudulent misrepresentation of age. In Stocks $v$ Wilson Lush J held that the Court could in equity compel the infant to restore property or money acquired by procuring an unenforceable contract through misrepresentation of age, ${ }^{15}$ but in Sheill Lord Sumner doubted whether recovery could extend beyond the actual property which passed under the contract. ${ }^{16}$ Although Stock was not expressly overruled, it seems to be that recovery in equity was limited to the specific property obtained in instances of fraudulent misrepresentation by minors as to their age. ${ }^{17}$

The common law appears to have viewed the occasional swindled moneylender as collateral damage in the effort to provide protection to infants. If such protection is legitimately the dominant consideration, it would certainly have been of little consolation to innocent traders duped by those "juvenile knaves" who managed to exploit the system. ${ }^{18}$

$12 \quad R$ Leslie Ltd $v$ Sheill [1914] 3 KB 607.

13 Ibid, at 612 Lord Sumner, citing Jennings $v$ Rundall (1799) 8 TR 335 (KB) at 337 per Lord Kenyon.

14 R Leslie Ltd v Sheill, above n 11, at 612.

15 Stocks $v$ Wilson [1913] 2 KB 235 at 247 per Lush J.

16 Reslie Ltd $v$ Sheill, above n 11, at 619 per Lord Sumner.

17 John D McCamus "Restitution of Benefits Conferred Under Minors' Contracts" (1979) 28 UNBLJ 89 at 114.

$18 \quad$ R Leslie Ltd $v$ Sheill, above n 11, at 612. 


\section{ENFORCEABILITY UNDER THE ACT}

The Minors' Contract Act 1969 was enacted as a code, replacing the previous common law, equitable and statutory rules relating to minors' contracts from 1 January $1970 .{ }^{19}$ Much of the Act was based on recommendations and suggestions made in the 1967 report of the United Kingdom Committee on the Age of Majority, a large portion of which was dedicated to the law of minors' contracts.

With respect to enforceability, the original Act divided minors' contracts into three categories:

(1) Contracts of married minors;

(2) Contracts of minors aged between 18 and 20, life insurance contracts of minors over 16 and contracts of service;

(3) All other minors' contracts.

The first category was covered by s 4 - contracts of married minors had effect as if the minor were of full contractual capacity. ${ }^{20}$ Section 4 was repealed by a 2005 amendment to the Act, after which married minors have the same contractual capacity as unmarried minors. ${ }^{21}$

Contracts in the second category are covered by s 5, although today s 5 applies only to life insurance contracts and contracts of service, the 2005 amendments having given full contractual capacity to minors aged 18 and over. ${ }^{22}$ These contracts are binding on the minor and enforceable against the minor, but the court may intervene if the consideration given for the minor's promise was so inadequate as to be unconscionable, or where any provision of the contract imposed a harsh or oppressive obligation on the minor. ${ }^{23}$ In such circumstances the court may cancel the contract, decline to enforce the contract (or make a declaration of unenforceability), or make any order for compensation or restitution of property it considers just. ${ }^{24}$

Contracts in the third category are dealt with by s 6 . Any contract not covered by s 5 is presumed to be unenforceable against the minor. However, the court is given various discretionary powers to intervene, depending on whether the contract was fair and reasonable at the time it was

19 Minors' Contracts Act 1969, s 15(1).

20 Minors' Contracts Act 1969, s 4(1).

21 Minors' Contracts Amendment Act 2005, s 4.

22 Minors' Contracts Act 1969, s 5. Despite having contractual capacity a person remains legally a minor until he or she reaches 20 years of age: Age of Majority Act 1970, s 4.

23 Minors' Contracts Act 1969, s 5(2).

24 Ibid. 
entered into. ${ }^{25}$ Under the original Act the court could, upon application, enforce a fair and reasonable contract against the minor or make a declaration of enforceability. In any case the court could make an order entitling other parties to cancel the contract, and could make orders for compensation or restitution. An amendment to the provision in 1971 set out the courts' powers more explicitly:

(2) The Court may, in the course of any proceedings or on application made for the purpose, inquire into the fairness and reasonableness of any contract to which subsection (1) of this section applies at the time the contract was entered into and-

(a) If it finds that any such contract was fair and reasonable at that time it shall not be obliged to make any order but it may in its discretion-

(i) Enforce the contract against the minor:

(ii) Declare that the contract is binding on the minor, whether in whole or in part:

(iii) Make such order entitling the other parties to the contract, on such conditions as the Court thinks just, to cancel the contract:

(iv) Make such order as to compensation or restitution of property under section 7 of this Act as it thinks just; and

(b) If it finds that any such contract was not fair and reasonable at that time it shall not be obliged to make any order but it may in its discretion-

(i) Cancel the contract:

(ii) Make such order entitling the minor, on such conditions as the Court thinks just, to cancel the contract:

(iii) Make such order as to compensation or restitution of property under section 7 of this Act as it thinks just.

Section 6(3) sets out factors that must be taken into account in exercising the court's discretion:

(3) In exercising its discretion under subsection (2) of this section the Court shall have regard to-
(a) The circumstances surrounding the making of the contract:
(b) The subject-matter and nature of the contract:
(c) In the case of a contract relating to property, the nature and the value of the property:
(d) The age and the means (if any) of the minor:
(e) All other relevant circumstances

Section 7 outlines how the court may exercise its discretionary powers under ss 5 and 6 . If the court decides to exercise its discretion and make an order of compensation or restitution, the court 
may vest all or part of any property that was the subject of or consideration for the contract in any party to the proceedings, or direct any party to transfer or assign any property that was the subject of or consideration for the contract to any other party. ${ }^{26}$

Parliament declined to adopt the recommendation of the Latey Committee that liability in deceit be allowed for cases where minors make fraudulent misrepresentations unrelated to age, although $\mathrm{s}$ 15(4) provides that such misrepresentations should be taken into account when deciding whether to exercise discretionary powers under ss 5 or 6 .

The Act also preserved the ability of a minor to enter into a fully binding contract with the approval of the Magistrate's Court (now the District Court). ${ }^{27}$ This measure was introduced in an amendment to the Infants Act 1908 in 1951, and had proved a useful tool for minors, at least where the contract was of sufficient significance to justify the effort and expense of going to court.

\section{APPLICATION OF THE ACT}

As mentioned, in the 40 years since the Minors Contracts Act was passed the court has been asked to give serious thought to the interpretation of its provisions on only two reported occasions. The High Court was not asked to consider the circumstances in which its discretionary powers under the Act could be exercised until the case of Morrow \& Benjamin Ltd v Whittington in $1989-20$ years after the original Act was passed. ${ }^{28}$

\section{$A$ Morrow \& Benjamin v Whittington}

Morrow \& Benjamin involved an Auckland stockbroking firm that had transferred on credit to the minor defendant shares valued at over $\$ 35,000$. The defendant, aged 17 at the time, was the son of a well-known customer and had worked for the firm as a clerk during school holidays. However, when the stockmarket crashed in October 1987 the defendant, after realisation of the value of his shares, was left owing Morrow \& Benjamin just over $\$ 30,000$. Morrow \& Benjamin applied for a declaration of enforceability of the contracts for the sale and purchase of shares on credit under $\mathrm{s}$ $6(2)$.

Thorp J considered the paucity of judicial consideration of the Act to be evidence of the Act's effectiveness as a balance between protection of young people and minimisation of meddling in the affairs of innocent adults. ${ }^{29}$ On this basis he took a conservative approach to interpreting s 6 . His Honour held that the differences between the language used in s 5 (unconscionability, harshness and oppressiveness) and s 6 (fairness and reasonableness) meant that the threshold at which the court's

Ibid, s 7(2).

Ibid, s 9 .

Morrow \& Benjamin Ltd $v$ Whittington, above $\mathrm{n} 1$.

Ibid, at 124 . 
discretionary powers could be engaged was different in each scenario. The Judge considered that the s 5 threshold was limited in its definition to the terms of the contract themselves, whereas a fairness and reasonableness threshold could go beyond the contract itself and take account of the circumstances surrounding the making of the contract. ${ }^{30}$

A difficulty with this analysis was that assessment of surrounding circumstances was expressly required under s 6(3) as part of the inquiry into how, having already determined the fairness and reasonableness of the contract, the court should exercise its discretionary powers. This suggests that surrounding circumstances ought to be considered in connection with this latter inquiry, and not the inquiry into the fairness and reasonableness of the contract. Thorp J briefly entertained the notion that the intention of the legislation was to exclude consideration of the age of the minor from the initial inquiry, but concluded that this could not be right on the basis that such an interpretation would introduce an unwarranted gloss on the word "reasonable", effectively confining its meaning to reasonableness between consenting and informed adults. ${ }^{31}$ Instead the Judge resolved to move on to the s $6(3)$ inquiry. ${ }^{32}$

Thorp $\mathrm{J}$ found himself unable to exercise any discretionary powers on the following bases: ${ }^{33}$

(1) The firm had been fully aware of the defendant's minority, and was also aware of the legal issues with respect to enforcing contracts against minors;

(2) The investments made by the defendant were highly speculative and took place within an increasingly volatile market environment;

(3) The firm had made inquiries about the defendant's means, and was advised that he had been given $\$ 10,000$ to invest by his father. The firm nevertheless advanced well over $\$ 30,000$ worth of shares on credit;

(4) The firm had failed to implement its normal credit controls with respect to the defendant, despite its view that the defendant was "unhelpful, casual and arrogant".

Thorp $\mathrm{J}$ applied those same factors to the inquiry into fairness and reasonableness, and concluded that the contracts, although fair, were not reasonable, preferring to give the term "reasonable" its ordinary meaning. ${ }^{34}$

In declining to make an enforcement order the Judge observed: ${ }^{35}$

$\begin{array}{ll}30 & \text { Ibid, at } 126 . \\ 31 & \text { Ibid, at } 127 . \\ 32 & \text { Ibid. } \\ 33 & \text { Ibid. } \\ 34 & \text { Ibid. }\end{array}$


If a substantial firm of stockbrokers chooses to allow a 17 year old it regards as "casual and arrogant", and whom it knows has been gambling with the credit it had previously given him, over $\$ 35,000$ credit for the purchase of highly speculative stocks, at a time when the market is recognised by it to be in a chaotic state, it should not be surprised if the Court does not view the case as one which calls for an enforcement order.

The decision in Morrow \& Benjamin was clearly correct. The credit contracts into which the minor entered, which involved investments of large amounts of money into volatile stocks, were evidence in themselves of naivety and inexperience from which the law seeks to protect minors. The firm that closed its eyes to this and allowed the minor to proceed could hardly expect relief in such circumstances. It should be noted, however, that the case was decided principally on the conclusions of the s 6(3) inquiry, and not under s 6(2). Because the inquiry into how the discretion should be exercised had indicated to Thorp $\mathrm{J}$ that relief for the plaintiff would be inappropriate in any event, the conclusion on the prior inquiry into fairness and reasonableness was not crucial to the decision. This is significant, as his Honour had been understandably tentative about his conclusion on the assessment of fairness and reasonableness.

\section{B Wine Country Credit Union v Rayner ${ }^{36}$}

Nearly 20 years passed before the High Court was required to consider these matters again. In 2007 the Wine Country Credit Union appealed a Napier District Court decision declining to make orders of enforceability or restitution in respect of a $\$ 15,612$ loan advanced to two minors for the purpose of purchasing a motor vehicle. The defendant minors had failed to make any repayments on the loan, and the car had been impounded when the first defendant was caught driving without a license. After repossession and sale of the car a balance of nearly $\$ 12,000$ remained owing. The credit union argued that because its loans officer had miscalculated the ages of the defendant minors, who were respectively about 3 and 6 months shy of their 18th birthdays, it entered the contract with no knowledge of the defendants' minority.

The case was complicated by the fact that although the defendants had provided their correct birth dates, they had been untruthful about other matters relevant to the contract. The defendants presented themselves as living together in a de facto relationship, when in fact they had taken up with each other only two or three weeks previously. The first defendant had misrepresented himself as holding a current driver's license and the second defendant had claimed a weekly income of $\$ 350$ on the loan application when in fact she was working part-time for about $\$ 60$ per week. The loan application had been completed on the defendants' behalf by the car dealer and forwarded to the loans officer, who then interviewed the defendants.

35 Ibid, at 128 .

36 Wine Country Credit Union v Rayner [2008] 1 NZLR 698 (HC). 
The credit union was referred to by District Court Judge Noble as "something of an institution in the Hawke's Bay". ${ }^{37}$ It had been founded by and for the benefit of catholic parishioners in the Hastings district in 1965, and by the time of the hearing its area of service had expanded to include all residents of "the land district of Hawke's Bay". ${ }^{38}$ The approach of the credit union to depositors and borrowers was categorised by counsel as "friendly", and the Judge inferred that "the ethos of the Plaintiff is to deal with its borrowers on as informal basis as possible in the hope that with its assistance they will prosper and one day become depositors". ${ }^{39}$ The loan officer gave evidence to the effect that the usual practice was to accept the car dealer's statements regarding applicants' financial positions, ${ }^{40}$ and the Judge was left with the impression that the granting of the particular application was "virtually automatic". 41

Applying Thorp J's approach from Morrow \& Benjamin, Judge Noble took full account of the surrounding circumstances in assessing the fairness and reasonableness of the contract. $\mathrm{He}$ concluded that the credit union ought to have known that the defendants were minors, and that more sensible scrutiny of the application by the credit union would have revealed the true nature of the defendants' financial positions. ${ }^{42}$ The Judge inferred from the rejection of a subsequent loan application by the defendants that if this had occurred the loan would never have been made, ${ }^{43}$ and therefore the contract was not reasonable. ${ }^{44}$ Given that the same factors would apply to the s $6(3)$ inquiry, neither an enforceability order nor an order for restitution was considered appropriate.

The credit union challenged both conclusions in the High Court. It argued that the reasonableness of the contract ought to be assessed on the content of the contract and not on surrounding circumstances, that Judge Noble had been wrong in holding that a finding of unreasonableness meant the Court was unable to exercise its discretion under s 6, and that the Judge was wrong to hold that a finding of unreasonableness precluded an order for compensation or restitution under $\mathrm{s} 7.45$

37 Wine Country Credit Union v Rayner and Tuhua DC Napier CIV 2004-041-000623, 11 May 2007 at [11] per Judge Noble.

38 See "History" Wine Country Credit Union < www.wccu.org.nz/Site/About/History> (accessed 7 July 2009).

39 Wine Country Credit Union v Rayner and Tuhua, above n 37, at [11].

40 Ibid, at [13].

41 Ibid, at [14].

42 Ibid, at [30].

43 Ibid.

44 Ibid, at [31].

45 Wine Country Credit Union v Rayner, above n 3, at [17]. 
The High Court was not impressed with any of these arguments. Allan J endorsed Thorp J's approach to assessing fairness and reasonableness in Morrow \& Benjamin, and held that a normal interpretation of the word "reasonable" must allow for consideration of circumstances surrounding the making of the contract. ${ }^{46}$

Regarding the exercise of discretion his Honour pointed out the demanding threshold that must be met before an appellate court will interfere with the first instance Judge's exercise of discretion. The credit union had argued that in refusing to exercise the Court's discretion Judge Noble had placed too much weight on the errors made by the credit union in processing the application and had failed to give sufficient weight to the defendants' deceptive conduct. ${ }^{47}$ Allan J held that Judge Noble had clearly considered all of these factors, and that it had been open to him to give more weight to the credit union's mistakes in deciding whether to exercise the discretion. ${ }^{48}$

In response to the final argument Allan $\mathrm{J}$ acknowledged that under $\mathrm{s} 6(2)(\mathrm{b})(\mathrm{iii})$ it was technically open to the Court to make an order for compensation or restitution even where the contract was unenforceable due to unreasonableness. However, he said that such an order would rarely be made where the effect would be to practically enforce an unenforceable contract, although it could be used to regularise the position where property had passed under the "contract". 49

\section{Summary of the Law}

Where a contracting party applies to the court for an order enforcing a contract against a minor under s 6(2) of the Minors' Contracts Act 1969, the court may only exercise its discretion to make such an order where the court is satisfied the contract was fair and reasonable at the time it was entered into. Morrow \& Benjamin held that in determining fairness and reasonableness the court should have regard not only to the content of the contract itself, but also to any relevant circumstances surrounding the making of the contract. Once fairness and reasonableness have been determined, the court must, in exercising any of its discretionary powers under the Act, have regard to the matters specified in s 6(3), which will necessarily involve repeat consideration of those circumstances already considered in the initial inquiry on fairness and reasonableness.

Section 6 provides for the court to make discretionary orders for compensation or restitution under s 7 regardless of whether the contract is enforceable. However in the event that a contract is

\footnotetext{
46 Ibid, at [27].

47 Ibid, at [29].

48 Ibid, at [32].

49 Ibid, at [34].
} 
unenforceable such orders will be unlikely where their effect would be to "place the parties in the same position as if the contract was fully binding". 50

\section{ANALYSIS OF RAYNER}

The High Court's determination in Wine Country Credit Union v Rayner allowed the minor defendants to borrow over $\$ 15,000$, repudiate the agreement entirely, having never made a single repayment, and avoid any obligation to return any of the money they acquired, while the credit union was left with a loss of nearly $\$ 12,000$, along with the costs of two failed court actions. It is difficult to see how legislation that was designed to "give a proper degree of protection to young people against exploitation whilst at the same time doing greater justice than the present law does to the fair and honest trader"51 could possibly deliver such an outcome, and it is arguable that in Rayner it should not have. It is submitted that the High Court made three vital errors, which may have led to the incorrect conclusion:

(a) The Court was wrong in holding that its exercise of discretion should ordinarily follow the finding as to the fairness and reasonableness of the contract under s 6(2).

(b) The Court was wrong in holding that an order under $\mathrm{s} 7$ requiring the defendants to return the loan money would have been tantamount to enforcement of the contract.

(c) The Court was wrong in holding that justice was best served by declining to make such an order in this case.

\section{A Must the Exercise of Discretion Follow the Finding as to Fairness and Reasonableness?}

Both the District Court and High Court in Rayner took the view that an exercise of judicial discretion in favour of the plaintiff would be inappropriate where the contract was held not to be fair and reasonable. Allan J held in the High Court that: ${ }^{52}$

Where a contract is held not to be fair and reasonable at the time it was entered into, then in ordinary

circumstances the orders that follow will tend to reflect that primary conclusion.

In my view this conclusion is incorrect.

The approach seems to be based on Thorp J's conclusion in Morrow \& Benjamin that substantially similar facts are relevant both to the s 6(2) inquiry into fairness and reasonableness and the s 6(3) inquiry into how judicial discretion ought to be exercised. This appears to have led both courts to make an unjustifiable link between the results of the two inquiries. With respect, it does

\footnotetext{
50 Ibid.

51 Hon J R Hanan, Minister of Justice (4 June 1969) 360 NZPD 496.

52 Wine Country Credit Union v Rayner, above n 3, at [34].
} 
not follow that because similar facts are relied upon in each, the conclusion of the latter inquiry should ordinarily reflect that of the former.

While the two inquiries will often involve consideration of similar aspects of the case, it should not be supposed that the facts that are common to both inquiries are relevant in the same ways. The scope of circumstances that may be taken into account is significantly wider under s 6(3) than s 6(2), which allows only for consideration of circumstances at the time the contract was entered into. Under s 6(3) the court is not prevented from taking into account matters subsequent to the contract, such as the post-contract dealings between the parties, or changes in the value of the property that was the subject of the contract, when determining whether and how discretion should be exercised.

Even where facts are common to both inquiries the reasons they are relevant to each will not necessarily correspond. The means of the minor, for example, are relevant to the s 6(2) inquiry because it may be unreasonable for an adult party to contract with a minor it knows lacks the means to service the debt, but under s 6(3) the minor's means are relevant to whether it would be just in the circumstances to require the minor to transfer money or property to the other party. These are separate inquiries, and in my view there is no reason why the conclusion of the first should dictate that of the second.

The crucial factor is that the courts are empowered under the Act to make discretionary orders regardless of the outcome of the s 6(2) inquiry - essentially all that is determined by s 6(2) is whether those orders will include orders of enforcement, or whether they will be limited to remedies of cancellation or compensation and restitution. The obvious conclusion is that the s 6(3) assessment must be conducted whether or not the contract is fair and reasonable, as a judicial discretion will be exercisable in either event. However, if it is true that the exercise of discretion will ordinarily follow the court's conclusion with respect to s 6(2), it is difficult to see how the assessment under s 6(3) can have any relevance at all where the contract is held to be unenforceable. A finding of unfairness or unreasonableness effectively strips the exercise of any relevance. This cannot be the result the legislation was intended to produce. It is suggested instead that the very reason s 6(3) is included in the legislation is to allow for orders to be made which do justice independently of the enforceability of the contract.

Comments in the House during the Parliamentary Debates on the Minors' Contracts Bill strongly support this contention. Most importantly, in summarising the purpose of clause 7 of the Bill, the Right Honourable John Marshall, Minister of Justice, commented that: ${ }^{53}$

...to prevent minors from being unjustly enriched as a result of the operation of the law, the court is given very wide power to grant relief to parties of contracts that are unenforceable against minors either under the provisions of the Act or by the decisions of the courts themselves.

53 (10 September 1969) 363 NZPF at 2677 (emphasis added). 'Jack' Marshall assumed the justice portfolio after Ralph Hanan died in July 1969. 
Parliament thus clearly considered that even where contracts did not meet the proposed "fair and reasonable" threshold for enforceability, there would be some instances where it would be just to grant relief to adult parties even though their contracts were unenforceable. The clear intention of Parliament was to provide for wide judicial powers to ensure such relief would be available whether the contract was enforceable or not.

In my view Allan J's approach in Rayner fails to recognise the intended "very wide power". His Honour appears to have erroneously circumscribed the Court's powers by making jurisdiction contingent upon the result of the s 6(2) inquiry into whether the contract was fair and reasonable - a matter which is necessary to determine enforceability but not at all determinative of whether or how discretion should be exercised.

The Minors' Contracts Act has provided specifically for discretionary orders to be made whether the contract is fair and reasonable or not. There is no particular reason why the exercise of discretion should tend to follow the finding as to fairness and reasonableness. On the contrary, it is suggested that the unenforceability that accompanies a finding of unfairness or unreasonableness will in many cases mean that some sort of discretionary order will be necessary to achieve a just outcome. Such a case may well be where a minor procures an unenforceable contract by his or her own wrongdoing, for example by misrepresenting one's age or capacity to service a loan.

\section{B Is an Order Requiring a Minor to Repay a Loan Advance Tantamount to Enforcement?}

In Rayner the plaintiff credit union argued that if its contract with the defendants was not fair and reasonable for the purposes of s 6(2), and was therefore unenforceable, the credit union was nevertheless entitled to be paid the amount outstanding from the loan by way of restitution. ${ }^{54}$ The High Court refused to make a restitution order on the basis that to do so would amount to enforcing an unenforceable contract: ${ }^{55}$

Technically it is open to a Court to award compensation or make an order for restitution under s 7 where

a contract has been held to be unenforceable under s 6(2)(b), but as a matter of common sense it will be

rare for the Court to hold on the one hand, that a contract was not fair and reasonable, and on the other

hand, to award restitution in order to place the parties in the same position as if the contract was fully

binding.

As discussed, the policy of the common law has been prohibitive of back door enforcement of contracts against minors through other causes of action. The rule that a minor could not be liable in tort for procuring a contract by fraudulent misrepresentation of age, which was a product of this policy, was expressly preserved by s 15(4) of the Act. What is less clear is whether Parliament

Wine Country Credit Union v Rayner, above n 3, at [17].

55

Ibid, at [34]. 
intended a continuation of this policy that would prevent an adult party recovering through an order for restitution under the Act, where the practical effect of that order might be seen as similar to enforcement.

Where contracts have been avoided or held unenforceable and the court is called upon to resolve the situation, a restitutionary remedy effectively reverses the contractual process, returning both parties to their original position before the contract was entered into. Benefits received under the contract are returned to the party that conferred them. An enforcement remedy, by contrast, moves the process forward, sometimes all the way to the bargained-for conclusion. Parties are compelled to hold up their ends of the bargain, or compensate the other parties for their failure to do so.

The difficulty with loan contracts is that under both enforcement and restitution remedies the borrower is required to pay the loan back to the lender. The remedies may appear very similar, at least for practical purposes. Allan $\mathrm{J}$ clearly took the view in Rayner that the similarity was sufficiently close that to allow recovery through restitution would undermine the policy of the Act to protect minors through unenforceability. This view is incorrect - restitution is not the same as enforcement, and any similarities between the two remedies are not so exact that an order for restitution would undermine the policy of the legislation by allowing for "back door" enforcement of an unenforceable contract.

Restitution and enforcement are not one and the same. Enforcement of a contract requires the parties to perform their agreement or make compensation for their failure to do so, whereas restitution simply restores benefits conferred to the party that conferred them, so that no party is unjustly enriched by the failed transaction. In Rayner a restitutionary order would have required the defendants to pay back the loan, less the resale value of the repossessed car - a balance of around $\$ 12,000 .{ }^{56}$ However if the contract had been enforced the defendants would have been liable for a much greater sum. Contractual interest charges for the term of the loan would have been payable, and perhaps penalties for missing instalments and resale costs as well. The credit union in Rayner claimed interest in the area of $\$ 5686$, meaning the defendants may well have been liable for close to $\$ 17,000$ had the contract been enforceable. ${ }^{57}$ Therefore it cannot be correct to say that the making of a restitutionary order requiring the defendants to repay the balance of the original loan would have been tantamount to making an order enforcing the contract.

Neither could it be said that making such an order would undermine the Act's policy of protecting minors through presumed unenforceability. Recovery through restitution is limited to the

The law of restitution also allows for interest to be awarded to the extent that it is part of the value of the benefit conferred on the debtor. See Goff and Jones The Law of Restitution (7th ed, Sweet \& Maxwell, London, 2007) at 30 . Such interest would likely be far less than the 16.95 per cent per annum contracted for in Rayner.

57 Email from Anna McCurrach to the author regarding the Rayner case (13 August 2009). 
benefits conferred on the other party under the unenforceable contract. Therefore a lender, no matter how unscrupulous, cannot hope to circumvent the unenforceability of a minor's contract by luring the minor into a loan contract and then profit by claiming restitution - it cannot get back more than it gave to the minor. Restitution is not a form of "back door" enforcement, but merely a means of reassigning property that has passed under the unenforceable contract. It provides no incentive to the adult contractor - indeed the credit union in Rayner, even if it had recovered through restitution, would still undoubtedly have been in a worse position than if it had never contracted with the defendants at all. There can therefore be no justification for concern that orders for restitution would undermine the protection the Act provides to minors through presumed unenforceability. Clearly, as discussed above, the architects of the Act held no such concern.

\section{Does the Act Provide for an Order for Restitution in Rayner?}

The Act provides for compensation or restitution orders where the contract is not fair and reasonable. ${ }^{58}$ However the courts have viewed this power conservatively. In Rayner Allan J held:59

For the most part s 7 will be utilised by the court where a contract has been held to be unenforceable, in order to regularise the position between the parties. For example, it may be necessary, in order to achieve justice, for the court to direct that a minor must reassign to the other contracting party property acquired by the minor but not paid for.

Obviously Allan J took the view that requiring the defendants to pay the balance of the funds acquired through the loan agreement would have gone further than "regularising" the parties' positions. It is difficult to determine exactly what his Honour meant by his use of this term, but it is likely that he intended to emphasise the Court's ability under s 7 to grant such relief as it thinks just. It would clearly be contrary to justice in Allan J's example to allow the minor to retain property acquired but not paid for. The question is whether the Court's decision in Rayner, which left the credit union around $\$ 12,000$ out of pocket while the minor defendants walked away debt-free, was in accordance with justice, or whether further orders were required to "regularise" the parties' positions.

The Speech of the Minister of Justice in the course of the parliamentary debates on the Minors' Contracts Bill exhibits some frustration at minors being able to walk away from their obligations at the expense of innocent traders and lenders: ${ }^{60}$

In its anxiety to protect young people against exploitation and harsh bargains, the law has given rise to consequences that can be most unfair to honest traders. As the law stands, a minor is entitled to

\footnotetext{
58 Minors' Contracts Act 1969, s 6(2)(b)(iii).

59 Wine Country Credit Union v Rayner, above n 3, at [34].

60 (10 September 1969) 363 NZPD 2676 (emphasis added).
} 
repudiate an agreement and at the same time keep any benefit he has received under it without having to pay compensation. To my mind - and, I am sure, that of all members of this House-that is one of the most serious defects in the present law.

In my view the result in Rayner is actually an example of the kind of situation the Minors' Contracts Act was intended to avoid. The defendants in Rayner were able to repudiate their loan agreement and keep the benefit of the loan without having to compensate the Credit Union. Although in this case the defendants managed to lose their acquired benefit through their own misadventures, I see no reason why justice should require that the credit union suffer the consequences of that loss. It should be recognised that the benefit conferred on the defendants was the $\$ 15,612$ lent by the credit union, and not the car that the money was used to purchase.

Admittedly, the case is complicated by the fact that the car purchased with the loan advance was also the security for the loan, and the car had already been assigned to the credit union and resold. If the loan advance was used to purchase the car, and the car was repossessed and resold for the benefit of the lender, it might be asked whether the lender had not already recovered the benefit it conferred on the minor.

If this complication is removed the unfairness of the High Court's decision becomes much clearer. Let us suppose that the loan in Rayner had been unsecured, and instead of purchasing a car the minors had used the loan money to throw a series of lavish parties for their friends. It is submitted that few would consider absolving the minors of their debt and forcing the lender to wear the loss to be the just result. If this is so, then where a minor's wasteful purchase happens to be of the item that is the security for the loan, it can surely be no more just to allow the minor to walk away debt-free and leave the lender to bear the loss of the difference between the amount advanced and the resale value of the security than it would have been to require the lender to take responsibility for all of the loss. Justice will not necessarily be achieved by the minor simply handing over the property acquired with the loan money

The Act's requirement that the Court make orders that it thinks just in exercising its discretion under $\mathrm{s} 7$ is not inconsistent with an order requiring the defendants in Rayner to repay the money advanced to them under the unenforceable contract. In fact it is suggested that such an order would have better achieved Allan J's stated goal of "regularising" the position between the parties - the credit union would have recovered the money wrongly conferred under the unenforceable contract, and the defendants would have avoided the additional fees and interest associated with enforcement. Admittedly there are aspects of s 6(3) that may ultimately have counted against such an order being made, but Allan $\mathrm{J}$ was wrong to hold that justice precluded an order requiring the defendants to return the money to the credit union.

\section{Conclusion on Rayner}

While it must always be remembered that the courts' powers under the Act are discretionary, the High Court's errors in Rayner could well have led to the case being wrongly decided. Both the 
District Court and High Court were wrong in holding that the exercise of discretionary powers was ruled out by a finding of unenforceability, Allan $\mathrm{J}$ made a serious error in suggesting that a restitutionary remedy would be tantamount to enforcement of the unenforceable contract, and the decision is clearly contrary to the intentions of Parliament. From a purely common sense perspective it seems decidedly unjust that a minor should be able to enter a contract to borrow a large sum of money and then be absolved of the debt, having made no payments, and having caused substantial loss to the innocent (although perhaps imprudent) lender. In my view the correct application of the Act does not support this conclusion.

\section{OPTIONS FOR REFORM}

The High Court's misapplication of the enforceability provisions in Rayner suggests that some reform is required to avoid further cases where minors receive benefits under unenforceable contracts and yet escape any obligation to make reparation to an innocent adult party.

\section{A A Possible Redraft}

Section 6(2) would benefit from an additional provision making it clear that the inquiry into fairness and reasonableness is separate from the s 6(3) inquiry into how the court's discretion should be exercised. My suggestion for such a provision is the following:

(c) For the avoidance of doubt, no orders as to compensation or restitution of property under section

7 in favour of other parties to the contract shall be precluded by reason only of a finding under this

subsection that any such contract was not fair and reasonable.

This provision would prevent courts from incorrectly relying on unfairness and unreasonableness as grounds for declining to make compensation or restitution orders, and would ensure that the inquiry under s 6(3) is undertaken independently of s 6(2).

Some reform is also required to ensure that s 7 is used appropriately by the courts. The legislation must make clear that remedies of compensation and restitution are different from enforcement, even if they sometimes appear similar, and that the court should not decline to make such orders based on any apparent similarity if making an order would best achieve justice in the particular case. This could be achieved by adding a third subsection, such as the following:

(3) No order for relief made pursuant to subsection (1) of this section shall be precluded by reason

only that the granting of such relief would provide a remedy similar in effect to enforcement or partial

enforcement of the contract.

Such a provision would ensure that the making of compensation or restitution orders is done in accordance with justice in the particular case, and would avoid unnecessary and irrelevant comparisons with enforcement remedies.

Addition of these or similar provisions to the Act should help to avoid repetition of decisions like Rayner, by ensuring that the courts make discretionary orders independently of the outcome 
into the fairness and reasonableness of the contract, and instead focus on achieving the outcome that would be most just in the particular case.

\section{B Removal of the "Fair and Reasonable" Threshold}

It might, however, be preferable to go beyond a mere redraft overturning Rayner, and instead alter the structure of the Act to better reflect the present commercial reality. It is arguable that the "fair and reasonable" threshold in s 6(2) retains no useful purpose in today's commercial environment. Most traders and lenders, as they did with "necessaries" under the previous law, have preferred to avoid the complications and risks of engaging the threshold by not dealing with minors at all. Moreover, it is unlikely now that any reform of the law providing for greater liability for minors would lead traders and lenders to relax this policy. ${ }^{61}$

Additionally, if provision is made for compensation and restitution orders to be made with more regard to justice in the particular case (as required by s 7) and less regard to their resemblance to enforcement, such orders could be sufficient to protect against fraudulent conduct by unscrupulous minors seeking to exploit their protections under the law without having to resort to enforcement remedies. It should be noted that ss 6 and 7 provide for compensation as well as restitution, and it is suggested that this may empower the court not only to order the return of benefits wrongly conferred under the contract (as restitution), but also to order parties to compensate other parties for losses suffered. This may allow wrongful behaviour by minors to be remedied without having to resort to complex and confusing enforceability thresholds.

It is suggested that the Legislature might consider whether the "fair and reasonable" threshold is obsolete. If it is, perhaps it should consider removing it from the Act totally, in favour of absolute unenforceability supplemented by compensatory and restitutionary orders, in order to better reflect commercial reality, and provide greater certainty in cases where minors' contracts occur.

\section{CONCLUSION}

There can be little doubt that the Minors' Contracts Act 1969 was and continues to be an improvement on the previous law on minors' contracts. However judicial and academic comment citing the paucity of case law as indicative of the Act's success have oversimplified the position. It is submitted instead that lenders and traders have been unable to gauge accurately whether contracts with minors could be enforced or not, and so the prudent solution has been simply to decline to deal with minors at all. The effect of the Act has been to shut down contracting with minors altogether, and where no contracts are made, no contracts can be tested by the court.

Moreover the courts' reliance on the "fair and reasonable" inquiry as a barometer for determining how remedial orders might be made under s 7 further diluted the "very wide power"

61 United Kingdom Law Commission Law of Contract: Minors' Contracts (Working Paper No 81, London, 1982) at 30. 
that Parliament had intended the courts to exercise in providing relief for parties to unenforceable contracts. The courts seem to have unnecessarily conflated the two inquiries, which had clearly been deliberately separated out in the Act. Additionally the High Court's failure in Rayner to recognise that justice allowed for a restitutionary order for return of the loan, and its erroneous conflation of the concepts of restitution and enforcement are likely to have further disadvantageous effects for innocent adult parties.

Changes to the legislation are necessary to avoid repeating the errors in Rayner. This could be achieved by redrafting ss 6 and 7 to address the courts' misapplication of the Act in Rayner, but in light of the current commercial environment, and recognising that we are now 40 years on from the passing of the Act into law, Parliament should consider whether the time has come to remove the "fair and reasonable" threshold from the Act in order to achieve greater certainty in the law of minors' contracts. 
